\title{
A Study of Determinant Factors Towards the Quality Teaching Among Teachers at Primary School in Bentong District
}

\author{
Ain Atiqah Syaqilah Fauzi \\ BBA (Hons) Operations Management \\ Faculty of Business and Management \\ UiTMCawangan Terengganu \\ Terengganu, Malaysia \\ Syaqilahfauzi94@gmail.com \\ Nik Noor Afizah Azlan \\ Faculty of Business and Management \\ UiTMCawangan Terengganu \\ Terengganu, Malaysia \\ nikno561@ tganu.uitm.edu.my
}

\begin{abstract}
The quality of teaching among the teachers is important in order to improve the students' achievement as well as improving the quality of education to students. In order to do that, teachers need to look deeper into ways to transform old classrooms and teaching styles into 21st century teaching and learning environments.Furthermore, teachers who teach in the classroom need to be creative in order to attract the student participation in class. This paper is written to determine the relationship between quality learners, quality of learning environment and quality teaching process on quality of teaching. In order to do so, a study has been done for a total of 165 respondents which is the teachers at primary school in Bentong district. Then, a set of questionnaires were distributed to the identified teachers in the area of Bentong, Pahang, Malaysia.The result of thisstudy eventually revealed that there were relationship between quality learner and quality teaching process with quality teaching among the teachers at primary schoolin Bentong district.Thus, the result of this research will help the schools, education department and decisionmakers to better understand the quality of teachings among teachers. It also can give new phenomenaon exploring new strategies to improve student's performance.
\end{abstract}

Keywords-Quality teaching, quality learner, quality learning environment, quality teaching process.

\section{INTRODUCTION}

Education is regards as one of the important needs and wants to the people. If people have better education and skills, it can help them to face the challenging world in the future especially for the next generation. Give education to the children from pre-school up to the highest level of the education made people to be able to improve and enhance

\author{
Nasiha Abdullah \\ Faculty of Business Management \\ UiTMCawangan Terengganu \\ Terengganu, Malaysia \\ nasiha@tganu.uitm.edu.my
}

\author{
Ahmad Suffian Mohd Zahari \\ Faculty of Business and Management \\ UiTMCawangan Terengganu \\ Terengganu, Malaysia \\ ahmadsuf@tganu.uitm.edu.my
}

the future's life. Education can be described as the ability of a person to manage their life because economic and social factors of individuals depend on education level that had been accepted. Weak in education will encourage individuals to live in poverty compared to the individuals with high literacy skills in education. According to [1], education is a social institution that has been around since the earliest human civilization and it serves to pass on culture, tradition, science, thought, and life skills from generation to generation.Thus, the focus of school today is to prepare students for college or employment in a field of their choice. Many schools have begun to change to accommodate these needs.

The term of 21st-century skills is generally used to refer certain core competencies such as collaboration, digital literacy, critical thinking, and problem solving that advocates the needs of schools in order to help students thrive in today's world [2]. According to [3] the characteristics of a 21st century classroomaremore to student-centred, that contain computing devices, active learning engagement, adaptive learning, and inviting environment. Teachers, who were involved to embrace $21 \mathrm{st}$ century learning,should provide their students with opportunities for hands on learning, creative expression, writing to reflect, justifying their answers, and collaborating with peers [4].

A study conducted by [5] found that students are more engaged, receptive and open to learn when 21st century learning styles are in place.However, with that being said, test scores did not increase as much as expected, when the information was taught in a tech-heavy student centered way, as compared to those who were taught a traditional, teacher-driven ways. They did increase, but just not as much as expected. Students were then taught in a blended form of instruction and that showed increased engagement, as well as increased knowledge retention. Therefore, teachers need 
to look deeper into ways to transform old classrooms and teaching styles into 21 st century teaching and learning environments. Nowadays, many school systems are driven to focus on the improvement of students' academic achievement through increase school accountability mechanisms and increase the stakes associated with performances [5].

Based on the researcher's observation, most of the teachers at primary school in Bentong district focused on the target student only while they are teaching in their classroom. However, the other students who are not performing in academic wouldn't be encouraged to participate in the classroom. That teaching process which is biased toward the student in class will not help the students to improve in their academic achievement. According to [6], good academic achievement depends on a variety of factors. The factors may have a good or bad influence to a child's ability to stay motivated and succeed in school. According to [7], the students who are not performing well in academic need more attention from the teachers to improve their studies. If the teachers do not teach them well while they are in primary school, it will affect their academic performance while they go to the next grade and also to their future too. If this problem not be solved, that students will fall behind in the study.

There is another problem that researcher found at primary school in Bentong District. Some of the students have their own interest and willingness to learn more, some of them don't have the interest to learn or study especially at school. So that, the students who have interest in study always perform well in the academic compared to the students who do not have the interest to study.

According to [8], the degree of the academic achievement of a student in the learning process depends on their attitude, interest and motivation issues. According to [7], teachers in the classroom need to be creative in order to attract their student to focus in class. In this $21^{\text {st }}$ century, the teachers need to use $21^{\text {st }}$ century learning style to attract the student's attention and their interest to participate in the class. This learning style also can improve the students' interest because $21^{\text {st }}$ century learning style needs the students to be active in class, especially for the activity such as presentation in group, school exercise in pairs, puzzle game and many more.

Quality learning environment is an influencing factor for teachers in order to get quality teaching. Based on the researcher's observation, some of the primary school at Bentong district have problem on building condition, facilities and school environment. The students who get enough facilities at school can achieve better performances in academically compared to the students who get not enough facilities at school. Based on the previous research by [8] which was done in Latin America, a study included 50,000 students in grade three and four found that children whose schools lacked classroom materials and had an inadequate library were significantly more likely to show lower test scores and higher grade repetition than those whose school were well equipped [9]. A school which had not enough facilities and environment condition will make teachers difficult to teach their students. The students also need support material in the class and comfortable environment in order to get more understanding and focus for the lesson in class. If the children more understand in study, they can improve in their academic achievement. Therefore, the objective of this research is to analyze the relationship between quality teaching among teachers at primary school in Bentong district with quality learners, quality learning environment and quality teaching process,

\section{LITERATURE REVIEW}

Organization that realizes the factors influence of quality teaching will enhance the organization to increase the performance of students especially in academic performances. The organization needs to increase the training for the teachers and take the action in a school environment in order to achieve quality teaching and better academic achievement among the students.

\section{A. Quality Teaching $(Q T)$}

According to [10], quality teaching is the use of pedagogical techniques to produce learning outcomes for students. Quality teaching included several dimensions such as the effective design of curriculum and course content, a variety of learning contexts (including guided independent study, project-based learning, collaborative learning, experimentation, etc.), soliciting and using feedback, and effective assessment of learning outcomes. It also involves well-adapted learning environments and student support services.

A teaching comprises the principles and methods used for instruction which implemented by teachers to achieve the desired learning for students. Teaching should be chosen primarily on the basis of the types of learning objectives because learning objectives as a guide for teachers to teach their students in class. As an instructor or teacher, they should consider other factors such as the availability of the technology necessary to implement the particular method [11]. That means, every activity that create by teachers must be consider the availability of the sources and materials. These strategies are determined partly on subject matter to be taught and partly by the nature of the learner. For a particular teaching to be appropriate and efficient, teachers need to look at the characteristic of the learner and the suitable type of learning it is supposed to teach about. In today's school the trend is that it encourages teachers to be creative in teaching.

Next, the additional factors that need to be included in the teaching method are students learning style and motivation level of the students. There are certain teaching skill such as the communication among students and pairing work activity. That skill can be the cooperative learner exercise which may help them to be more motivate and be more effective for certain learning style [11]. When, the learners have the high motivation to learn, students can 
perform better in education and also improve in their academic achievement. The highest the achievement of the student performance, that means the teachers achieve their learning objective. That means, the teacher have the quality teaching towards their students.

Given that, the most relevant aspect of the teachinglearning process are essentially contained in the work of teachers and students in the classroom. Number of students and the number of teachers in a school did not relate to the impact of implementing the quality teaching except in certain specific areas. It is impossible that the perception of the impact of quality management plans on teachinglearning processes varied more depending on the number of students in a classroom than the size of the school itself [12]. Based on the researcher observation, the number of students is not given impact in order to achieve the quality teaching among the teachers at primary school in Bentong district but the teaching skill that used by the teachers itself give the biggest impact to the students' performances in class. The teachers need to be creative in order to attract the students to focus in class and influence them to response in the class and do the exercise given.

\section{B. Quality Learners $(Q L)$}

The learner can be defined as a someone who is learning about a particular subject or how to do something such as students at school, university, college or even in an organization. School systems work with the children who come into them in order to get the education service. The life of the students before getting formal education greatly influences the kind of learner they can be. There are many elements needed in making a quality learner, including health, early childhood experiences and home support [10]. School is a place for the educational services. While, children are people who receive the service.So, the children come to the school to get the best education.

The first thing needed in order to prepare a child to become a quality learner is giving good nutrition and health care. A healthy child can influence them to learn well at school, especially in their academic. According to [13], "healthy development in early childhood, especially during their first three year life, plays an important role for them in order to provide their basis for a healthy life and a successful formal school experience". Adequate nutrition is important for normal brain development, especially in the early years, early detection and intervention for disabilities can give children the best chances for the healthy development. Healthy brain can help the students to think well, learning faster and easily understand what they have learnt at school. Every parent needs serve and giving nutrition food to their children in order to maintain their healthy body and brain. When the children have a good condition of body, they will be active in class at school and also can become a quality learner.

Next, home support, especially from the parents and sibling also is important to the children in order to be a quality learner. According to [9], "parents who are having higher education can influence the children to learn. In one study, which had been done by the previous researcher, children whose parents had primary education or less were more than three times as likely to have a lower score compared to the children whose parents had at least some secondary schooling". Parental education is not only influences the child interaction to learn, but also influences to their income which can help them to keep their children to school. Sometimes, brothers and sisters also can be a role model to a young learner. They will become interested to learn more whenever they see their successful brother and sister. They will keep an ambition to be a successful person in their heart. In other case, happiness family also influences the children to be a quality learner. It also can influence the children to learn well, which ever doesn't have family problems. Children whoever have problem family background will not perform well in study and also having bad behaviour. This case happens because of they don't have support from parents.

Furthermore, early childhood psychosocial development experiences also influenced the quality of learner. Positive early interactions and experiences are also vital to preparing to a quality learner. According to [8], "a large study of 12 Latin American countries found that younger children are associated with higher test scores and lower rates of grade repetition in the primary school if there are higher parental involvement". The parents who are reading to younger children also can help their children to learn fast. According to [13], good early childhood programmes give benefit to children to better psychosocial development. Effective and appropriate stimulation for children in early years can influence the brain development, especially for emotional regulation and behaviour management. A child who misses the positive stimulation faces the chronic stress in the preschool and also may have difficulty in psychosocial development later in life.

\section{Quality Learning Environment ( $Q L E$ )}

"School environment refers to social, academic and emotional contexts of a school, the personality of the learning context and how it is perceived by students, staff and community. This environment or climate is influenced by a broad range of factors, from disciplinary policies and instructional quality to student and teacher morale" [14].

Physical learning environment are the places, in which formal learning occurs, ranging from relatively modern and well equipped buildings in open-air gathering places. The quality environment seems to have an indirect effect on learning, that effect is hard to measure but some author argues about that. Extent of empirical evidence from the previous research by [15], the condition of school buildings is related to higher student achievement after taking into account student's background. "A previous research made in India had found sample 59 schools and found that of these buildings and of these, 25 had a toilet, 20 had electricity, 10 had a school library and four had a television", [16]. In this case, "the quality of the learning environment was strongly 
correlated with pupil achievement in Hindi" [16]. The classroom, library, laboratories, equipment and other places are the physical setting for learning where formal teaching is done. It is greatly affects the learner either positively or negatively. That means, the school needs to provide enough facilities in order to increase the achievement of the student's performance especially in academic. Other than that, a good school environment also can make student interested to go to school. They also can feel comfortable to learn if their school is clean, cheerful, calm, non-violent and beautiful.

Next, psychological environment for learning also can stimulate the students to learn in an effective and efficient way. The teachers need to create the interaction between the teachers and their students. That kind of atmosphere can attract the student to more focus in class. The result from the previous research shown that learning will proceed smoothly and enthusiastically if students see the relationship between them and their teachers. They will feel warmth and love. The students also need to see themselves as a participating actively in the process learning also in some decision that affect them. The psychological environment also has to do with the communication between a student to other students in the classroom. Children also need to be taught the spirit of co-cooperativeness and respect others [17]. The teachers who achieve their quality teaching also can give the biggest impact to the student in order to get the best lesson. The students who get the quality education at school, they can use and practice it in the future life.

Furthermore, community and family environment also an element of the learning environment for students in order to achieve quality in teaching. What happens at outside the classroom also affect the process of learning. We know that child's first school is home. The experiences and ideas that they get from their parents and siblings help them to advance the work of the school. Actually, they need to play supporting role with the child by the everyday care about their education at school [17]. The parents also need to help and teach the children to do the homework. Teach them if they have not understood. Sometimes, parents also can buy their children the additional resources for their study such as magazines, books and newspapers. That item also can encourage the children to interest in reading and also can increase their knowledge too. According to [10], " the quality of school buildings may be related to other school quality issues, such as the presence of adequate instructional materials and textbooks, working conditions for students and teachers, and the ability of teachers to undertake certain instructional approaches.

\section{Quality Teaching Process (QTP)}

The teaching process is a set of interrelated beliefs and values, which is generally known as 'conception of teaching'. Conception of teaching is a term that refers to a teacher's value, belief and intention towards teaching. The teachers' understanding about conceptions of teaching can affect their teaching as influences the quality of the student's learning [18]. There are two conceptions of teaching which are student-centred and teacher-centred. According to [7], teachers at the school are encouraged to use student-centred learning which the teachers only become a facilitator in the class. Teachers only facilitating students' learning, give instruction to students and support the students' learning. Nowadays, there are many teaching processes that have been established by the Ministry of Education for student-centred learning such as i-think, icare, high order thinking skills (HOTS) and 21st century learning.

Firstly, the students need profesional teachers to teach them at school. The excellence teachers, those the most capable of helping their students learn. The teacher who gets the excellent teacher award at school actually has their own way to help their students in academic. The students' academic performance can be improved [7]. Furthermore, the teachers needs to make the preparation before start the lesson in the class. The preparation is to helps and guide the teacher about what the activity that they want to do in class. Based on the result from the previous research, the teachers who make the preparation before beginning their lesson were able to help the students to learn well [19]. Other than that, the excellent teachers also give the biggest impact in order to get the quality teaching among the teacher.

Next, excellent teacher should help the other teachers to develop their teaching skill and take new understanding about how children learn. Furthermore, the curriculum for the 21 st century student should be on the student-centred not on the teachers-centred yet. The curriculum also should be relevant and an instructional method. The teaching which the teacher talk and do a presentation in the class is no longer fits to the current students because of their understanding are different than the 80th students. Instructions, should help students build on prior knowledge to develop attitudes, beliefs and cognitive skills as well as expand their knowledge base [2]. Actually, those teachers who practice in the 21 st century learning can help the students to improve their understanding on study and also can attract the students' interest to study. Based on the research that had been done in Bangladesh, greater understanding of student-centred learning can be encouraged through a Bangladeshi project on multiple ways of teaching and learning which helps improve teachers' skills by integrating basic research and multiple intelligences theory as the foundations for understanding children needs [20]. Students-centred learning method is facilitating the students to be active in learning rather than being a passive student. When the students active in class, they can understand faster than the passive students. That means, the students get quality education if the teacher practices that quality teaching process.

Lastly, an active or standard-based participatory methods also an element of the quality teaching process in order to achieve the quality teaching. The education that supports and empowers both teachers and students through democratic processes increasingly defines quality in the 21 st 
century [10]. The teacher needs to do more activities with students in order to attract the students to respond the teachers' question. The teachers also need to give a chance to all the students to participate in class. Among other things,this type of learning activity promotes critical thinking among students, problem solving learning, teamwork and community involvement [10]. So that, it can help the students to be more understanding in their study. It also can help students to improve in their performance. Thus, before beginning the class, teachers need to be creative and thinks about the activities that they must do with the students. So that the students can achieve their success criteria that given by teachers and teachers also can achieve their own objectives.

Based on the identified from the literature review, there were many factors that contribute the quality teaching. Here more that eight factors from the previous journal that were studied by the authors. However, for this study, the researcher only interpreted four factors which are quality teaching, quality learner, quality learning environment and quality teaching process in order to achieve and complete this study.

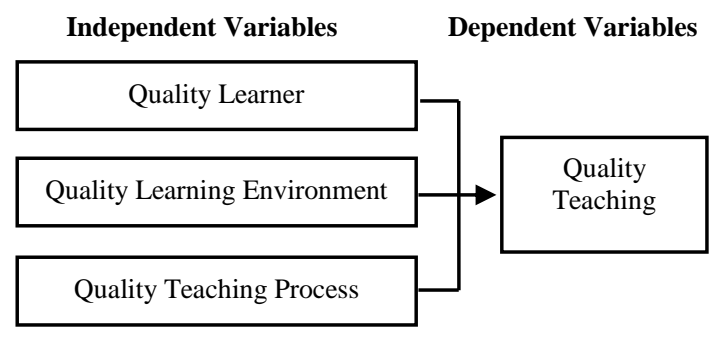

Fig.1: Theoretical Frameworks

The following theoretical framework has been adopted from previous research and literature. Thetheoretical framework illustrates the overall relationship between the independent variables and dependent variables of the study. The independent variables are quality learner, quality learning environment and quality teaching process and thedependent variable is qualityteaching.

This paper seeks to address the following objectives:

1. To investigate the influence of quality learneron quality teaching.

2. To examine the influence of quality learning environmenton quality teaching.

3. To measure the influence of quality teaching process on quality teaching.

\section{Hypotheses}

H1 - There is a significant relationship between quality teaching and quality learner.

$\mathrm{H} 2$ - There is a significant relationship between quality teaching and quality learning environment.

H3 - There is a significant relationship between quality teaching and quality teaching process.

\section{METHODOLOGY}

The aim of this study is to determine the influence of quality learner, quality learning environment and quality teaching process on quality teaching. Therefore, to achieve the objective of the research, a quantitative correlation research design was used to examine the relationship between the three types of variables. The main instrument of this paper is a set of questionnaire. The items in the questionnaire are formulated to meet this research objective, although they were based from previous studies. This paper has been divided into five parts. It started with demographic questions of respondents, second part determined the dependent variable, third part, fourth part and fifth part determined the independent variables. Questionnaire in the second, third,fourth and fifth part were instructed in Likertscale format by using strongly disagree to strongly agree. The researchers adapted and adopted the question from the previous research. The samples of 165 responses were used in this study obtained as part of the survey. The survey had been conducted in the field of housing sector in Dungun, Terengganu, Malaysia. The entire of the questionnaires are distributed and collected directly from all housing buyers. The analysis of the questionnaires was done by using the Statistical Package in the Social Science Software (version 23.0) program for Windows for descriptive statistical analysis.

\section{A. Population}

The study was conducted among the primary school teachers in the Bentong district for thirteen school such as Sekolah Kebangsaan Felda Chemomoi, SK Felda Kemasul, SK Felda Mempaga 1, SK Felda Sungai Kemahal, SK Jambu Rias, SK Janda Baik, SK Kampung Shafie, SK Lebu, SK Lentang, SK Pelangai Jawi-Jawi, SK Simpang Pelangai, SK Sri Layang and SK Sungai Dua. The total number of population of teachers at primary schoolsin Bentong district is 294 teachers. It is based on the data givenby an officer at PPD Bentong who is managing the primary school. The respondents came from different age, race, education level and working experience years. Moreover, this study is focusing on determinant factor towards the quality teaching among teachers at primary school in Bentong district. The factors that are analysed in this study include quality learners, quality learning environment and quality teaching process. The data gathered by using some of approaches such as observation, interview and also by distributing questionnaires. The observation and interview were carried out to collect the information about the background of organization, number of primary school teachers, and the problem occurred in school. Whereas the questionnaires were distributed in order to collect the demographic information of primary school teachers and their perception about their teaching.

\section{B. Sampling}


There are altogether 13 schools of sekolah kebangsaan at Bentong district which include SKFC, SKFK, SKFM 1, SKFSK, SKJR, SKJB, SKKS, SKLB, SKLT, SKPJ, SKSP, SKSL and SKSD

TABLE 1: the numbers of teachers for each primary school at Bentong district.

\begin{tabular}{|l|c|}
\hline \multicolumn{1}{|c|}{ School } & Number of teachers \\
\hline Sk Felda Chemomoi & 35 \\
\hline Sk Felda Kemasul & 28 \\
\hline Sk Felda Mempaga 1 & 30 \\
\hline Sk Felda Sungai Kemahal & 18 \\
\hline Sk Jambu Rias & 20 \\
\hline Sk Janda Baik & 29 \\
\hline Sk Kg Shafie & 14 \\
\hline Sk Lebu & 26 \\
\hline Sk Lentang & 14 \\
\hline Sk Pelangai Jawi-Jawi & 20 \\
\hline Sk Simpang Pelangai & 23 \\
\hline Sk Sri Layang & 20 \\
\hline Sk Sungai Dua & 17 \\
\hline Total & $\mathbf{2 9 4}$ \\
\hline
\end{tabular}

The researcher used stratified random sampling technique to distribute the questionnaire to respondents. Based on the table 3.1 the total population of teachers at primary school in Bentong district is 294 people. From this population, the researcher managed to get appropriate sample size by refering to [21]. The sample size for this study is 165 of respondents.

\section{FINDINGS AND DISCUSSION}

\section{A. Introduction}

The data collection was carried out in the duration of 4 months beginning on 6 February 2017 until 2 June 2017. The research is carried out among teachers at primary school in Bentong district. Since the total of population of teachers at primary school in Bentong district is 294 peoples, the sample size chose to distribute for questionnaire is 165 teachers. It is based on [21] table. However, the researcher able to get 126 answered questionnaire from primary school teachers at Bentong district. Thus the data obtained is less accurate and generalized to represent the teachers at primary school in Bentong district. On the other hand, this chapter will analyse on descriptive analysis of demographic factors, reliability analysis for dependent variable and independent variables, correlation between variables and regression analysis for the model suggested in this study

\section{B. Reliability analysis}

The reliability analysis indicates how well the items in the set are correlated to one another. The reliability analysis is carried out to determine the reliability of the items for each variable. The researcher had distributed questionnaires to the primary school teachers at Bentong district. The result of Cronbach's Alpha for each variable as shown in table 2 as below:

TABLE2: The Cronbach's Alpha result

\begin{tabular}{|c|c|c|c|c|}
\hline & $\begin{array}{c}\text { Pilot } \\
\text { Test } \\
\text { Vo.of } \\
\text { item) }\end{array}$ & $\begin{array}{c}\text { Cronbach } \\
\text { Alpha }\end{array}$ & $\begin{array}{c}\text { Actual } \\
\text { Test } \\
\text { (No.of } \\
\text { item) }\end{array}$ & $\begin{array}{c}\text { Cronbach } \\
\text { Alpha }\end{array}$ \\
\hline QT & 10 & 0.828 & 10 & 0.877 \\
\hline QL & 10 & 0.867 & 10 & 0.898 \\
\hline QLE & 10 & 0.918 & 10 & 0.921 \\
\hline QTP & 10 & 0.844 & 10 & 0.920 \\
\hline
\end{tabular}

C. Quality teaching $(Q T)$

For the dependent variable of quality teaching, the result shows a very good strength of association with the value of Cronbach's Alpha for pilot test and actual test with value 0.828 and 0.877 . The total items for this variable are ten (10). Hence the result exceeds the value of 0.60 , it is considered as reliable.

\section{Quality learner $(Q L)$}

For the first independent variable which is quality learner, the result shows a very good strength of association for pilot test and actual test with the value of Cronbach's Alpha are 0.867 and 0.898 . The total items for this variable are ten (10) questions. Hence, the result exceeds the value of 0.60 , it is considered as reliable.

\section{E. Quality learning environment (QLE)}

For the second independent variable which is quality learning environment, the result shows an excellent strength of association for pilot and actual test with the value of Cronbach's Alpha are 0.918 and 0.921 . The total items for this variable are ten (10) questions. Hence, the result exceeds the value of 0.60 , it is considered as reliable.

\section{F. Quality teaching process (QTP)}

For the third independent variable which is quality teaching process, the result shows a very good strength of association for pilot test and an excellent strength of association for actual test with the value of Cronbach's Alpha are 0.844 and 0.920 . The total items for this variable are ten (10) questions. Hence, the result exceeds the value of 0.60 , it is considered as reliable.

\section{G. Frequency Distribution}

The demographic factors of the respondents consist of gender, race, age, level of education and no of years' work as teacher. The summary of the demographic factors is shown in table 3below. 
TABLE3: Frequency distribution result

\begin{tabular}{|c|c|c|c|c|}
\hline No & Profile & Description & Responses & Percentage \\
\hline \multirow[t]{2}{*}{1} & \multirow[t]{2}{*}{ Gender } & Male & 48 & 38.1 \\
\hline & & Female & 78 & 61.9 \\
\hline \multirow[t]{3}{*}{2} & \multirow[t]{3}{*}{ Race } & Malay & 103 & 81.7 \\
\hline & & Indian & 7 & 5.6 \\
\hline & & Chinese & 16 & 12.7 \\
\hline \multirow[t]{3}{*}{3} & \multirow[t]{3}{*}{ Age } & $\begin{array}{l}21-30 \\
\text { years old } \\
31-40\end{array}$ & 32 & 25.4 \\
\hline & & & 40 & 31.7 \\
\hline & & $\begin{array}{l}\text { years old } \\
51 \text { years } \\
\text { old and } \\
\text { above }\end{array}$ & 15 & 11.9 \\
\hline \multirow[t]{6}{*}{4} & \multirow[t]{6}{*}{$\begin{array}{l}\text { Education } \\
\text { Level }\end{array}$} & SPM & 1 & 0.8 \\
\hline & & STPM & 2 & 1.6 \\
\hline & & $\begin{array}{l}\text { Diploma } \\
\text { Bachelor's }\end{array}$ & 9 & 7.1 \\
\hline & & Degree & 102 & 81 \\
\hline & & Degree & 12 & 9.7 \\
\hline & & $\mathrm{PhD}$ & 0 & 0 \\
\hline \multirow[t]{5}{*}{5} & \multirow[t]{5}{*}{$\begin{array}{l}\text { No.of } \\
\text { working } \\
\text { years }\end{array}$} & $1-5$ years & 30 & 23.8 \\
\hline & & $\begin{array}{l}6-10 \text { years } \\
11-15\end{array}$ & 27 & 21.4 \\
\hline & & $\begin{array}{l}\text { years } \\
16-20\end{array}$ & 17 & 13.5 \\
\hline & & $\begin{array}{l}\text { years } \\
21 \text { years }\end{array}$ & 25 & 19.8 \\
\hline & & and above & 27 & 21.4 \\
\hline
\end{tabular}

Based on table 3 above, the result shows there are more female respondents than male respondents with a total number of 78 and 48 people respectively. This means that the female respondents have the highest percentage with $61.9 \%$ while the percentage for male respondents is $38.1 \%$.Next factor is the respondents' race. Majority of the respondents are Malay which carry a percentage of $81.7 \%$ with the total number of 103 peoples. This followed by $12.7 \%$ of respondent who are Chinese which about 16 peoples. The minority is come from Indian respondents which about 7 peoples represent $12.7 \%$ of the total population. Next factor is the respondents' age. Majority of the age between 31 to 40 years' old which carry a percentage of $31.7 \%$ with the total number of 40 peoples. This followed by $31.0 \%$ of respondent who age between 41 to 50 years' old which about 39 peoples. This followed by $25.4 \%$ of respondent who age between 21 to 30 years' old which about 32 peoples. The minority of respondents is grouped on above 51 years' old which about 15 peoples represent $11.9 \%$ of the total population.

The result also shows that 102 of them graduated from bachelors' degree which is equivalent to $81.0 \%$. This is followed by 12 respondents who graduated from masters' degree school and they recorded a percentage of $9.7 \% .9$ of the respondents graduated from diploma and their percentage is $7.1 \%$. The other 3 respondents have graduated from SPM and STPM and their percentage are $0.8 \%$ and $1.6 \%$ which is 1 of them have finished their education until SPM level. It can be concluded that most of the respondents have finished their education until bachelor's degree level.Last factor is the respondents' working years as a teacher. Most of the respondents have experienced as a teacher between 1 to 5 years which carry a percentage of $23.8 \%$ with the total number of 30 peoples. This followed by $21.9 \%$ of respondent who have working experiences as a teacher between 6 to 10 years and 21 years and above which about 27 peoples for each. This followed by $19.8 \%$ of respondent who have working experience between 16 to 20 years which about 25 peoples. The minority of respondents is grouped on 11 to 15 years which about 17 peoples represent $13.5 \%$ of the total population.

\section{H. Descriptive Analysis}

Descriptive analysis covers Part B which is the items for dependent variable and independent variables. Descriptive analysis shows the value of the mean for each item. Besides that, descriptive analysis also shows the results of median, mode, standard deviation and skewness for each variable.

TABLE4: Descriptive Statistic result

\begin{tabular}{|c|c|c|c|c|c|c|}
\hline \multirow{2}{*}{ Variable } & $\mathrm{N}$ & Mean & Median & Mode & $\begin{array}{c}\text { Std. } \\
\text { Dev. }\end{array}$ & Skewness \\
\cline { 2 - 5 } QT & 126 & 4.42 & 4.45 & 5.00 & 0.403 & -0.046 \\
\hline QL & 126 & 4.08 & 4.00 & 4.00 & 0.487 & 0.254 \\
\hline QLE & 126 & 4.32 & 4.35 & 5.00 & 0.524 & -0.223 \\
\hline QTP & 126 & 4.49 & 4.50 & 5.00 & 0.447 & -0.465 \\
\hline \hline
\end{tabular}

Table 4 shows the values for mean, median, mode, standard deviation and skewness for the variables including quality teaching, quality learner, quality learning environment and quality teaching process. The total number of questionnaires in the data set is recorded under the column labelled N. From this table there is no missing value for each variable.

The average answer for each variable is recorded in the mean column. The value of the mean for quality teaching is 4.42. Meanwhile the mean for independent variables of quality learner is 4.08 , quality learning environment with 4.32 and lastly quality teaching process with 4.49 . From this data, the researcher found that most of the respondents agreed with all variables in the questionnaire.

Next, the Median column refers to the respondent who is in the centre of the group. So out of 126 respondents, the $63^{\text {rd }}$ answer in order given by the respondents will determine the median for each variable. The value of median for quality teaching is 4.45 . Quality learner, quality learning 
environment and quality teaching process recorded the median values of $4.00,4.35$ and 4.50 respectively.

The Mode column indicates the value which received the highest frequency as selected by the respondents. The quality teaching, quality learning environment and quality teaching process shared the same value of mode which is 5 whereas the quality learner the mode value of 4 .

The dispersion or variability of answer given by the respondents can be assessed by examining the value of Standard Deviation for each variable. Hence, the more the variety of answer given by the respondents the larger the value of standard deviation will be. In contrast, if the respondents tend to give relatively the same answer, the standard deviation will be quite low. The standard deviation for quality teaching is 0.403 . Besides the standard deviation for quality learner, quality learning environment and quality teaching process are $0.487,0.524$ and 0.447 respectively.

\section{Correlation Analysis}

The purpose of correlation analysis is to determine the relationship between independent variables and dependent variable. Association between all variables need to be tested to ensure that all the independent variables are related to dependent variable. For this study, the relationship of independent variables such as quality learner, quality learning environment and quality teaching process tested with Pearson Correlation Analysis to examine the strength of association with dependent variable of quality teaching. Thus, the hypothesis developed can be supported by table5: beside shows the result of Pearson Correlation analysis.

TABLE5: Pearson Correlation analysis

\begin{tabular}{|c|c|c|c|c|c|}
\hline & & $\begin{array}{c}\text { Quality } \\
\text { Teaching }\end{array}$ & $\begin{array}{l}\text { Quality } \\
\text { Learner }\end{array}$ & $\begin{array}{l}\text { Quality } \\
\text { Learning } \\
\text { Env. }\end{array}$ & $\begin{array}{c}\text { Quality } \\
\text { Teaching } \\
\text { Process }\end{array}$ \\
\hline QT & $\begin{array}{l}\text { Pearson } \\
\text { Correlation } \\
\text { Sig. (2- } \\
\text { tailed) } \\
\mathrm{N}\end{array}$ & 126 & & & \\
\hline QL & $\begin{array}{l}\text { Pearson } \\
\text { Correlation } \\
\text { Sig. (2- } \\
\text { tailed) } \\
\mathrm{N}\end{array}$ & $\begin{array}{l}.605^{\text {** }} \\
.000 \\
126\end{array}$ & $\begin{array}{c}1 \\
126\end{array}$ & & \\
\hline QLE & $\begin{array}{l}\text { Pearson } \\
\text { Correlation } \\
\text { Sig. (2- } \\
\text { tailed) } \\
\text { N }\end{array}$ & $\begin{array}{l}.349^{* *} \\
.000 \\
126\end{array}$ & $\begin{array}{l}.473^{* *} \\
.000 \\
126\end{array}$ & $\begin{array}{c}1 \\
126\end{array}$ & \\
\hline QTP & $\begin{array}{l}\text { Pearson } \\
\text { Correlation } \\
\text { Sig. (2- } \\
\text { tailed) } \\
\mathrm{N}\end{array}$ & $\begin{array}{l}.682^{* *} \\
.000 \\
126\end{array}$ & $\begin{array}{l}.578^{* *} \\
.000 \\
126\end{array}$ & $\begin{array}{l}.534^{* *} \\
.000 \\
126\end{array}$ & 126 \\
\hline
\end{tabular}

From the table 5 above, all the independent variables which are quality learner, quality learning environment and quality teaching process have positive correlation coefficient which indicates that there is a positive linear relationship between independent variables and dependent variable. Thus, as the independent variable increase in value, it also will increase for the value of dependent variable. The twotailed significance test $(\mathrm{p}<0.01)$ proved that the outcome of the test is not by chance.

The correlation between quality learner and quality teaching in this study is $(r=0.605)$ which represent a strong relationship. The relationship between quality learner and quality teaching is significant at the 0.01 level at a value of 0.000 . Therefore, the hypothesis 1 is supported.

The correlation between quality learning environment and quality teaching in this study is $(r=0.349)$ which represent a weak relationship. The relationship between quality learning environment and quality teaching is significant at the 0.01 level at a value of 0.000 . Therefore, the hypothesis 2 is supported.

The correlation between quality teaching process and quality teaching in this study is $(r=0.682)$ which represent a strong relationship. The relationship between quality teaching process and quality teaching is significant at the 0.01 level at value of 0.000 . Therefore, the hypothesis 3 is supported.

In addition, all the correlation among independent variables (quality learner, quality learning environment and quality teaching process) is significant at the 0.01 level with positive relationship. Thus,this analysis will answer the first and second research objective which are to identify the relationship between quality teaching with quality learners, quality learning environment and quality teaching process and to identify which variables(quality learners, quality of learning environment and quality teaching process) has the strongest relationship to quality teaching.

\section{J. Multiple regression analysis}

Multiple regression analysis is used to examine the established functional relationship between the dependent variable of quality teaching with the series of independent variables consists of quality learner, quality learning environment and quality teaching process. From the regression analysis result, we can formulate the regression function. Table 6 below shows the summary of regression analysis.

TABLE6: Summary of Regression Analysis

\begin{tabular}{|c|c|c|c|c|c|c|}
\hline Summary & \multirow[t]{2}{*}{ Dim } & \multirow[b]{2}{*}{$B$} & \multirow[b]{2}{*}{$\mathrm{T}$} & \multirow[b]{2}{*}{ p. } & \multicolumn{2}{|c|}{$\begin{array}{c}\text { Collinearity } \\
\text { Statistics }\end{array}$} \\
\hline$\overline{\mathrm{R}^{2}}$ & & & & & Tolerance & VIF \\
\hline $.734^{\mathrm{a}} .539$ & QL & 0.282 & 4.394 & .000 & 0.629 & 1.591 \\
\hline ANOVA & QLE & -0.770 & -1.332 & .185 & 0.674 & 1.403 \\
\hline Sig. & QTP & 0.485 & 0.657 & .000 & 0.578 & 1.729 \\
\hline $47.454 .000^{\mathrm{b}}$ & & & & & & \\
\hline
\end{tabular}

R-Square is the proportion of variance in the dependent variable (quality teaching) which can be predicted from the 
independent variables (quality learner, quality learning environment and quality teaching process). This value indicates that $53.9 \%$ of the variance quality teaching can be predicted from the variables of quality learner, quality learning environment and quality teaching process. The remaining $46.1 \%$ of the model will be explained by others factors.

The F-value in the table is 47.454 and its marginal significant (Sig. $\mathrm{V}=0.000)$. The significant value which is associated with this $\mathrm{F}$ value is very small $(0.000)$. Thus, the significance level produced by the ANOVA table showed that the p-value is less than 0.05 implying that the model is valid and the result of the relationship is not by chance. Further analysis through regression, produces standardizes measures (Beta Weights) of the strength for each dimension's associations with quality teaching. $\beta$ is the values for the regression equation for predicting the dependent variable from the independent variable. Among the three independent variable; quality learner $(\beta 0.282$, $\mathrm{p}<0.000)$, quality learning environment $(\beta-0.770, \mathrm{p}<0.185)$, and quality teaching process $(\beta 0.485, \mathrm{p}<0.000)$, a variable is statistically not significant towards the quality teaching. That variable is the quality learning environment. Quality teaching process has the highest Beta value which indicates the most influential factor towards quality teaching. This followed by the independent variable with the second highest Beta value which is quality learner. From the result, only two variableswere significant towards quality teaching as a model.

The table above also shows the collinearity statistic result. It consists of tolerance value and VIF value. The tolerance value that is more than 0.2 that means there is no duplication for each variable in which the respondents did not feel confused between the variable. There is no similarity between the variable which enable the respondents to clearly distinguish them. A tolerance under 0.2 usually means that the variable has correlation with their independent variable and should not be included. It can be concluded that the tolerance value for this study is more than 0.2 which quality learner is 0.629 , quality learning environment is 0.674 and quality teaching process is 0.578

\section{CONCLUSION AND RECOMMENDATION}

\section{A. Introduction}

This chapter discusses on the main findings of this study and will conclude whether it is able to achieve for the research objectives. The focus of this research is to identify the most critical factor that influences quality teaching among the teachers at primary school in Bentong district. Moreover, the recommendation will be suggested by the researcher based on the finding of the research. The researcher also will propose for suggestions to improve the future researcher to carry out the research on this topic in the future. Last but not least, the researcher hopes that this research can give some benefits and act as a stepping stone for the teachers at primary school in Bentong district in order toimprove their quality teaching towards students and help the students to improve their academic performance.

\section{B. Conclusion}

Table 5 shows the relationship between quality teaching and quality learners. The result of the Pearson's correlation test indicates there is a strong relationship with a correlation value of 0.605 . In addition, there is a significant relationship between quality teaching and quality learners. The twotailed significance test $(\mathrm{p}<0.01)$ proves the result of the test is not by chance and can be confidently accepted. Secondly, the relationship between quality teaching and quality learning environment shows a weak relationship with the correlation value of 0.349 . In addition, there is a significant relationship between quality teaching and quality learning environment. The two-tailed significance test $(p<0.01)$ proves the result of the test is not by chance and can be confidently accepted. As a conclusion, there is a significant relationship between quality teaching and quality learning environment.

Thirdly is the relationship between the last independent variable which is between quality in teaching and quality teaching process. The test reveals there is a strong relationship between these variable with the correlation value of 0.682 . In addition, there is a significant relationship between quality teaching and quality teaching process. The two-tailed significance test $(\mathrm{p}<0.01)$ indicates the result of the test is not by chance can be confidently accepted. As a conclusion, there is a significant relationship between quality teaching and quality teaching process.

The table summary of regression analysis shows that two independent variables which are quality learner and quality teaching process are significant with the dependent variable of quality teaching. While the other independent variable which is quality learning environment is insignificant towards quality teaching. Thus, the researcher concludes that quality learner and quality teaching process are the major contributors that influence quality in teaching among the primary school teachers in Bentong district.

\section{Recommendation}

After analyzing the three factors (quality learner, quality learning environment and quality teaching process), the researcher found out that the application of these three dimensions of quality teaching able to improve for the better teaching among teachers at primary school in Bentong district. Hence, the researcher would like to suggest the headmasters of the primary schools to focus on developing the aspects of quality learner and quality teaching process at the school. The most critical factor that teacher needs to be improved is the teaching process while in the classroom.

\section{Quality Learner}

Since quality learner has a significant effect on the quality teaching, the teachers at primary school in Bentong district should motivate and encourage their students to participate in class and join all the activities in class in order 
to improve their knowledge and also attract their interest to learn more in class. Motivation is purposely to increase their interest towards study for gaining knowledge and improved their academic achievement. The motivation that an individual experiences can affect their attitudes, beliefs, intentions and effort. Thus, teachers need to be creative to create more activities while teaching in class [7]. As an example, the teachers can practise $21^{\text {st }}$ century learning skill in class in order to encourage the students' participation. $21^{\text {st }}$ century learning skill is included collaboration, communication, critical thinking and creative thinking among the students. According to [7], there are some of the teachers have success to improve their teaching skill and students' performance by using $21^{\text {st }}$ century learning skill.

\section{E. Quality Teaching Process}

The finding also showed that quality teaching process is the most critical factor that influenced quality teaching. Since quality teaching process has a significant effect towards quality teaching, the management, such PejabatPendidikan Daerah, Ministry of Education and government need to arrange training programme for teachers in order to improve their teaching skill. Training is important to teachers because the teachers who can deliver quality instructions can bring about good student academic performance. For the example, PejabatPendidikan Daerah Bentong held a training programme contribution with Pahang Foundation and Tellal Institute with the English teachers. Students need a teacher who is willing to provide them opportunities to learn in ways that works best for them. Teachers must view themselves as guides, rather than presenters. It has been proven repeatedly, that teachers as guides, freedom of choice and technology integration set students up to success, lifelong learners [2].

\section{$F$. Suggestion for future research}

Lastly, as a recommendation for future researchers, for the purpose of comparison, the researcher can also try to distribute the questionnaire at the primary school and secondary school in another district and states. The other factor of increasing the quality teaching also is suggested to be explored in future researches.

\section{REFERENCES}

[1] I. A. Bajunid. "Culture is our future: The past determines the future of Southeast Asia and East Asia." Paper presented at the building on our past and investing in our future: An International Seminar on Multidisciplinary Discourse, jointly organized by Fo Guang University, Taiwan and The National University of Malaysia. Selangor, Malaysia. 2004.

[2] N. Ondrashek. "21st Century Learning." Master's Theses \& Capstone Projects. Retrieved from http://nwcommons.nwciowa.edu/education_masters/21. (21). 2017.unpublished.

[3] W. B. Saxena. "Top 10 Characteristics of a 21st Century Classroom." Retrieved February 2, 2017, from http://edtechreview.in/news/862- top-10-characteristics-of-a-21stcentury-classroom. 2013.

[4] P. Goertz. "What does a 21 st century classroom look like: Technology integration." Retrieved March 1, 2017, from https://www.edutopia.org/discussion/what-does-21st-centuryclassroom-looktechnology-integration. March 31, 2015.

[5] W. Amosa, J. Ladwig, T. Griffiths, and J .Gore. "Equity effects of quality teaching: Closing the gap". Paper presented at the Proceedings Australian association for research in education conference. 2007.

[6] C. Murray, and K. Malmgren. "Implementing a teacher-student relationship program in a high-poverty urban school: Effects on social, emotional, and academic adjustment and lessons learned." Journal of School Psychology,Vol 43(2), 2005, pp 137-152.

[7] H. Mohamad. 2017, April 12. Personal Interview.

[8] J. D. Willms, and M.A. Somer. "Family, classroom, and school effects on childrens educational outcomes in Latin America." School effectiveness and school improvement, Vol 12(4), 2001, pp 409-445.

[9] J. D. Willms. "Standards of care: Investments to improve children's educational outcomes in Latin America." Paper presented at the Conference of Early Childhood Development, Washington, D.C. 2000

[10] UNICEF. "Defining quality in education." Paper presented at the A paper presented at the meeting of the International Working Group on Education, Florence, Italy. 2000.

[11] S. E. Bonner. "Choosing teaching methods based on learning objectives: An integrative framework." Issues in Accounting Education,Vol 14(1), 1999, pp 11-15.

[12] F. J. J. Cruz, I. Egido Galvez, and R. C. Santaolalla.). "Impact of quality management system on teaching-learning processes." Quality Assurance in Education, Vol 24(3), 2016, pp394-415.

[13] M. McCain, and F. Mustard. "Reversing the real brain drain: Early years study." Final Report to the Canadian Government, Children's Secretariat,10(75) 1999.

[14] A. Loukas, and S. Robinson. "Examining the moderating role of perceived school climate in early adolescent adjustment." Journal of Research on Adolescence, Vol 14(2), 2004, pp209-233.

[15] B. Fuller, L. Dellagnelo, A. Strath, E. S. B. Bastos, M. H. Maia, K. S. L. de Matos, and. S. L. Vieira. "How to raise children's early literacy? The influence of family, teacher, and classroom in northeast Brazil." Comparative education review, Vol 43(1), 1999, pp1-35.

[16] G. Carron, and T.N. Chau. "The Quality of Primary Schools in Different Development Contexts." 1996

[17] J. I. Dabo. "The Role of School Environment as a Determinant Factor For Quality Education in Bauchi State Primary School Nigeria." International Journal of Science Environment Vol 4(6), 2015, pp1480-1488.

[18] J. Kember. "A reconceptualization of the research to university academics' conception of teaching, learning and instruction." Vol (7), 1997, pp255-275.

[19] J. E. Mullens, R. J. Murnane, and J. B. Willett. "The contribution of training and subject matter knowledge to teaching effectiveness: A multilevel analysis of longitudinal evidence from Belize." Comparative education review, Vol 40(2), 1996, pp139-157.

[20] L. Ellison, and B. Rothenberger. "In Bangladesh: The Multiple Ways of Teaching and Learning." Educational Leadership, Vol 57(1), 1999, pp54-57.

[21] R.V. Krejcie, and D.W. Morgan. "Determining sample size for research activities." Educational and Psychological Measurement, Vol 30, 1970, pp 607-610. 